\title{
Homozygosity for SCN4A Arg1142Gln causes congenital myopathy with variable disease expression
}

Christine K. Sloth, MD, Federico Denti, PhD, Nicole Schmitt, PhD, Bo Hjorth Bentzen, PhD, Christina Fagerberg, MD, John Vissing, DMSci, and David Gaist, PhD

Neurol Genet 2018;4:e267. doi:10.1212/NXG.0000000000000267

Congenital myopathy has recently been associated with biallelic pathogenic variants in the $S C N 4 A$ gene that encodes the voltage-dependent sodium channel $\mathrm{Na}_{\mathrm{V}} 1.4{ }^{1,2}$ In 13 previously reported cases, ${ }^{1,2} 7$ died in utero or shortly after birth. The 6 survivors showed features consistent with "classical" congenital myopathy. Here, we report 2 new familial cases with variable phenotype.

Written informed consent was obtained from both patients. Permission for the study was granted by the Danish Data Protection Agency.

The index patient, an 18-year-old woman, born as the second of 2 children to consanguineous parents, reported weakness and dyspnea from early childhood. Pregnancy and birth were normal, but postpartum, she had dysphagia and was tube fed. Early motor milestones were delayed, with independent ambulation achieved at age 2.25 years and inability to lift her head from a supine position until age 3 years. She experienced improvement in her condition throughout childhood, but still had reduced walking distance $(2.5 \mathrm{~km})$, difficulty lifting heavy objects, and experienced patella luxations.

On examination, the patient is $150 \mathrm{~cm}$ tall and has a dolichocephalic head shape and elbow hypermobility (figure 1A). Strength testing showed diffuse muscle force reduction at Medical Research Council (MRC) grade 4, with no distal/proximal gradient, and axial weakness. Spirometry showed normal forced vital capacity (FVC) (88\%) and forced expiratory volume (FEV1) (96\%).

Creatine kinase (CK) levels and neurophysiologic findings were normal. Replacement of muscle by fat on MRI was pronounced in gluteus maximus and hamstring muscles (figure 1B). Muscle biopsy, at age 4 years, displayed myopathic features with varying fiber size, increased number of internalized nuclei, atrophic fibers, and endomysial fibrosis and fat infiltration.

Next-generation sequencing revealed homozygosity for a previously described missense variant in SCN4A (NM_000334.4: c.3425G>A(p.Arg.1142Gln)), ${ }^{2}$ confirmed through Sanger sequencing, and was deemed to be pathogenic by 6 prediction tools. Parents were heterozygous for the variant.

The 22-year-old sister of the index patient was also homozygous for Arg1142Gln. She had milder muscular complaints than her sister, which included difficulties lifting her head when lying down, exertional shortness of breath, and poor cycling capacity since childhood. She had elbow joint hypermobility like her sister. Her motor milestones were normal. Strength testing
Correspondence

Prof. Gaist

dgaist@health.sdu.dk

From the Department of Neurology (C.K.S., D.G.), Odense University Hospital; and Department of Clinical Research (C.K.S., D.G.), Faculty of Health Sciences, University of Southern Denmark, Odense; Department of Biomedical Sciences (F.D., N.S., B.H.B.), Faculty of Health and Medical Sciences, University of Copenhagen; Department of Clinical Genetics (C.F.), Odense University Hospital; and Copenhagen Neuromuscular Center, Department of Neurology (J.V.), Rigshospitalet, University of Copenhagen, Denmark.

Funding information and disclosures are provided at the end of the article. Full disclosure form information provided by the authors is available with the full text of this article at Neurology.org/NG.

The Article Processing Charge was funded by the authors.

This is an open access article distributed under the terms of the Creative Commons Attribution-NonCommercial-NoDerivatives License 4.0 (CC BY-NC-ND), which permits downloading and sharing the work provided it is properly cited. The work cannot be changed in any way or used commercially without permission from the journal. 

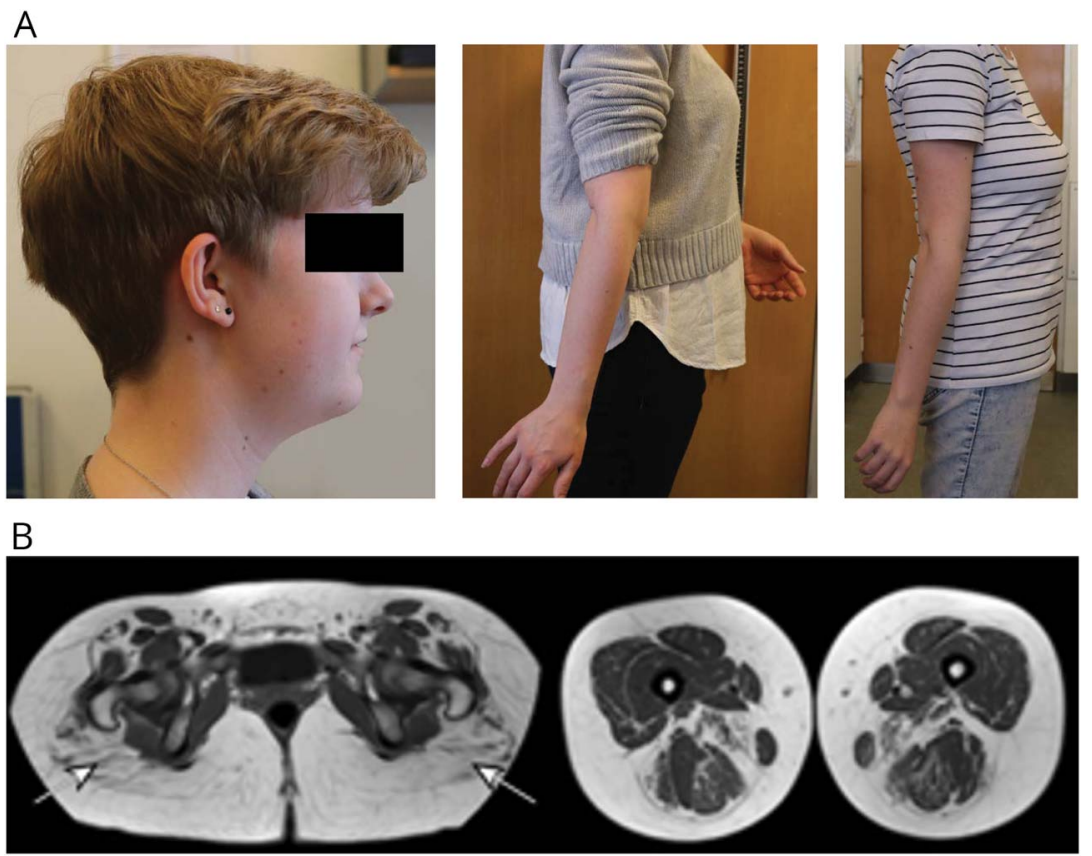

Featuring the dococephalic head form in the index patient (left image) and hypermobility of the elbows in both sisters (middle and right image) (A). T1-weighted muscle MRI images of the index patient show severe fatty infiltration and atrophy of gluteus medius (arrows, left image) and adductor magnus and, to a lesser degree, the hamstrings bilaterally (right image) (B).

Figure 2 The mutation R1142Q causes loss-of-function of Nav1.4 current

A

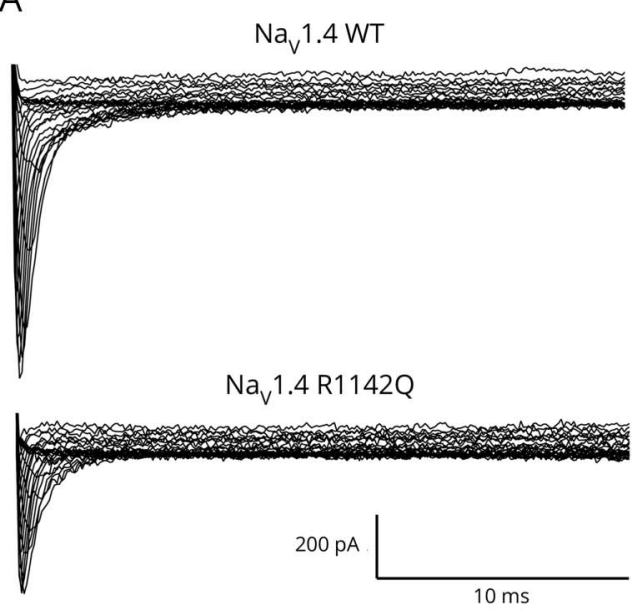

C

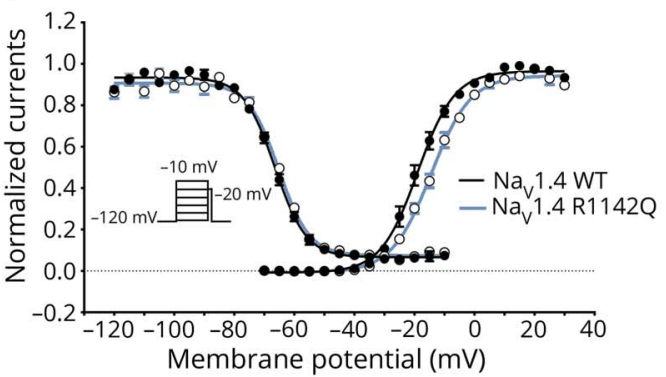

B

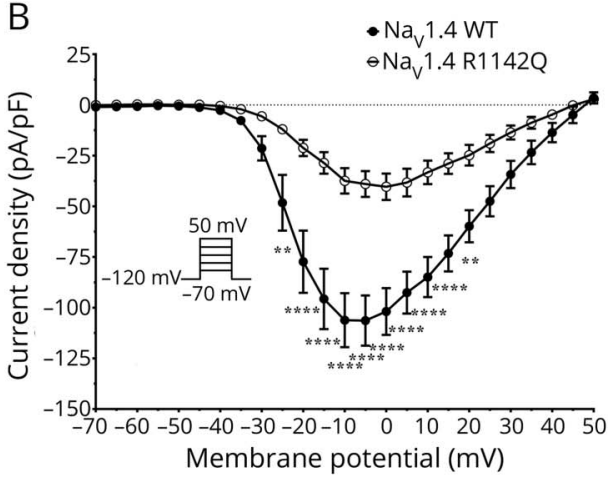

$\mathrm{D}$

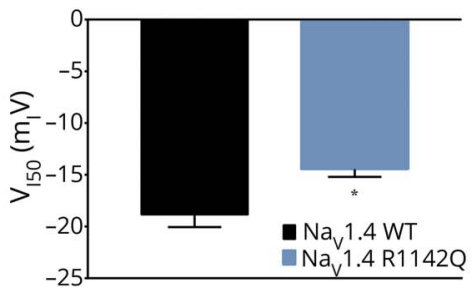

(A) Representative current traces for Nav1.4 WT and R1142Q recorded from transiently transfected HEK293 cells. (B) IN relationship for the peak current density for $\mathrm{Na}_{\mathrm{V}} 1.4$ WT $(\mathrm{n}=9)$ and R1142Q $(\mathrm{n}=8)$ Voltage protocol shown as inset. (C) Steady-state inactivation and activation curves for $\mathrm{Na} 1.4 \mathrm{WT}$ (black) and R1142Q (gray). Voltage protocol shown as inset. (D) Comparison of activation $V_{50}$ values between Nav1.4 WT (black) and R1142Q (gray). ${ }^{*} p<0.05 ; * \star p<0.006$; $* * \star * p$ $<0.0001$. 
showed reduced neck flexion (MRC 4+), shoulder abduction (MRC4+), and hip flexion (MRC 4+). CK, lung function tests, and MRI of thigh muscles were normal.

Functional assessment of the Arg1142Gln (R1142Q) variant in human embryonic kidney 293 (HEK293) cells revealed partial loss-of-function effects (figure 2), as previously reported in SCN4A-related congenital myopathy. ${ }^{1,2} \mathrm{Na}_{\mathrm{V}} 1.4 \mathrm{R} 1142 \mathrm{Q}$ peak current density was significantly lower than wild type (WT) (WT: $106.4 \pm 12.4 \mathrm{pA} / \mathrm{pF}, \mathrm{R} 1142 \mathrm{Q}:-39.0 \pm 6.4 \mathrm{pA} / \mathrm{pF}$ at $5 \mathrm{mV}$, figure $2, \mathrm{~A}$ and $\mathrm{B}$ ), and the voltage dependence of channel activation was significantly changed (figure $2, \mathrm{C}$ and D).

Variants in SCN4A were originally linked to congenital myasthenia, ${ }^{3,4}$ but recently, also to severe fetal hypokinesia and early lethality ${ }^{1}$ and to sudden infant death syndrome. ${ }^{5}$ A strikingly milder phenotype of "classical" congenital myopathy has been described in 6 patients with $S C N 4 A$ variants in a recessive pattern, only 3 of whom were adults (aged 18-35 years old). ${ }^{1,2}$ Our 18 -year-old index patient exhibited a phenotype similar to that previously reported, ${ }^{1}$ while her 20 -year-old sister was only marginally affected. Our index patient's characteristic muscle MRI findings were similar to 4 other patients with SCN4A mutations, including 2 brothers, compound heterozygous for c.3425G $>A(p . A r g 1142 G l n)$ and another missense variant c.1123T $>\mathrm{C}$ (p.Cys375Arg). ${ }^{1,2}$ The brothers, unlike our patients, had elongated faces, ptosis, facial weakness, scoliosis, and elevated $\mathrm{CK}^{2}$ We speculate whether homozygosity for the p.Arg1142Gln variant conferred the milder phenotype observed in our patients. The present report expands our knowledge regarding SCN4A-related congenital myopathy in adulthood and underscores that the phenotype of this disorder may vary considerably, even within members of the same family, as in other recessive channelopathies affecting muscles. ${ }^{6}$

\section{Author contributions}

C.K. Sloth: drafted the manuscript and performed administrative work. F. Denti: tested the effect of the SCN4A mutation in a cell line. N. Schmitt: tested the effect of the SCN4A mutation in a cell line, interpreted data, revised the manuscript, and drafted figures. B.H. Bentzen: tested the effect of the SCN4A mutation in a cell line. C. Fagerberg: in charge of DNA-testing of the 2 sisters and revised the manuscript.
J. Vissing and D. Gaist: design, revised the manuscript, interpreted clinical data, and drafted figures.

\section{Study funding}

This study did not receive external funding.

\section{Disclosure}

C.K. Sloth, F. Denti, N. Schmitt, B.H. Bentzen, and C. Fagerberg report no disclosures. J. Vissing has served on the scientific advisory boards of Sanofi Genzyme, aTyr Pharma, Ultragenyx Pharmaceuticals, Santhera Pharmaceuticals, Sarepta Therapeutics, Audentes Therapeutics, Novo Nordisk, Alexion Pharmaceuticals, and Stealth BT; has received travel funding and speaker honoraria from Sanofi Genzyme, Ultragenyx Pharmaceuticals, Santhera Pharmaceuticals, and aTyr Pharma; serves on the editorial boards of Neuromuscular Disorders and the Journal of Neuromuscular Diseases; has been a consultant for Sanofi Genzyme, Ultragenyx Pharmaceuticals, Santhera Pharmaceuticals, and aTyr Pharma; and has received research support from the Danish Medical Research Council, the University of Copenhagen, the Augustinus Foundation, the NOVO Nordic Foundation, and the Lundbeck Foundation. D. Gaist has received honoraria from AstraZeneca (Sweden) for participation as a coinvestigator in a research project and has received research support from the Danish Cancer Society. Full disclosure form information provided by the authors is available with the full text of this article at Neurology.org/NG.

Received June 26, 2018. Accepted in final form July 26, 2018.

\section{References}

1. Zaharieva IT, Thor MG, Oates EC, et al. Loss-of-function mutations in SCN4A cause severe foetal hypokinesia or "classical" congenital myopathy. Brain J Neurol 2016;139: 674-691.

2. Gonorazky HD, Marshall CR, Al-Murshed M, et al. Congenital myopathy with "corona" fibres, selective muscle atrophy, and craniosynostosis associated with novel recessive mutations in SCN4A. Neuromuscul Disord NMD 2017;27:574-580.

3. Tsujino A, Maertens C, Ohno K, et al. Myasthenic syndrome caused by mutation of the SCN4A sodium channel. Proc Natl Acad Sci USA 2003;100:7377-7382.

4. Arnold WD, Feldman DH, Ramirez S, et al. Defective fast inactivation recovery of Nav 1.4 in congenital myasthenic syndrome. Ann Neurol 2015;77:840-850.

5. Männikkö R, Wong L, Tester DJ, et al. Dysfunction of NaV1.4, a skeletal muscle voltage-gated sodium channel, in sudden infant death syndrome: a case-control study. Lancet 2018;391:1483-1492.

6. Sahin I, Erdem HB, Tan H, Tatar A. Becker's myotonia: novel mutations and clinical variability in patients born to consanguineous parents. Acta Neurol Belg Epub 2018 Feb 26. 


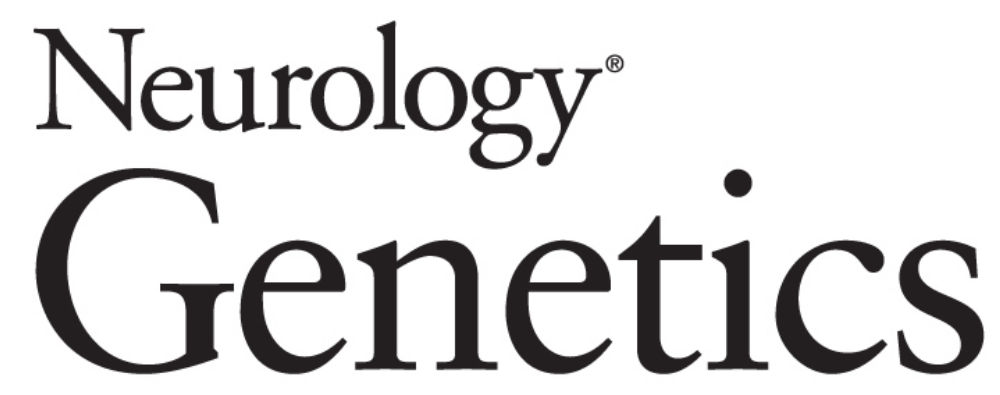

\section{Homozygosity for SCN4A Arg1142GIn causes congenital myopathy with variable disease expression}

Christine K. Sloth, Federico Denti, Nicole Schmitt, et al.

Neurol Genet 2018;4;

DOI 10.1212/NXG.0000000000000267

This information is current as of September 19, 2018

Updated Information \&

Services

References

Citations

Subspecialty Collections

Permissions \& Licensing

Reprints including high resolution figures, can be found at: http://ng.neurology.org/content/4/5/e267.full.html

This article cites 5 articles, 1 of which you can access for free at: http://ng.neurology.org/content/4/5/e267.full.html\#\#ref-list-1

This article has been cited by 1 HighWire-hosted articles: http://ng.neurology.org/content/4/5/e267.full.html\#\#otherarticles

This article, along with others on similar topics, appears in the following collection(s):

Ion channel gene defects

http://ng.neurology.org//cgi/collection/ion_channel_gene_defects Muscle disease

http://ng.neurology.org//cgi/collection/muscle_disease

Information about reproducing this article in parts (figures,tables) or in its entirety can be found online at:

http://ng.neurology.org/misc/about.xhtml\#permissions

Information about ordering reprints can be found online:

http://ng.neurology.org/misc/addir.xhtml\#reprintsus

Neurol Genet is an official journal of the American Academy of Neurology. Published since April 2015, it is an open-access, online-only, continuous publication journal. Copyright Copyright @ 2018 The Author(s). Published by Wolters Kluwer Health, Inc. on behalf of the American Academy of Neurology.. All rights reserved. Online ISSN: 2376-7839.

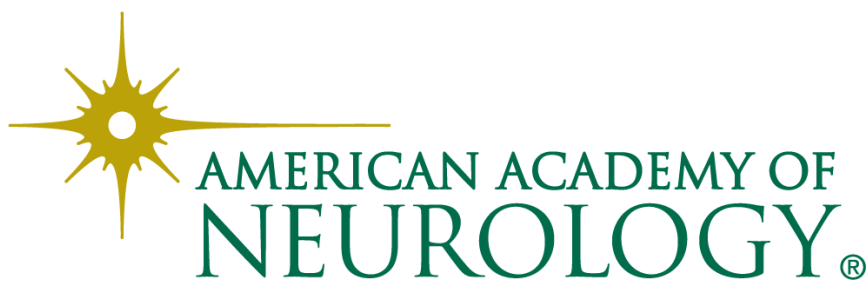

